\title{
The Prediction of Growth Yields in Methylotrophs
}

\author{
By CHRISTOPHER ANTHONY \\ Department of Biochemistry, School of Biochemical and Physiological \\ Sciences, University of Southampton, Southampton $\mathrm{SO}_{9} 3 \mathrm{TU}$
}

(Received I I July 1977; revised 9 September 1977)

\begin{abstract}
Equations have been developed for assimilation of methane, methanol, methylamine, dimethylamine, trimethylamine, formaldehyde and formate into cell material by bacteria using the ribulose monophosphate pathway, the ribulose bisphosphate pathway and the serine pathway of carbon assimilation. The equations have been used for predicting the effect on cell yields $\left(Y_{\mathrm{s}}, Y_{\mathrm{O}_{2}}\right.$ and $Y_{\mathrm{CO}_{2}}$ ) of various $\mathrm{P} / \mathrm{O}$ ratios, systems for substrate oxidation and assimilation pathways. The generalizations relating $\mathrm{P} / \mathrm{O}$ ratios and cell yields, which have been used previously for such calculations, are not always applicable to methylotrophs. In particular, for the majority of methylotrophs the growth yield is determined by NAD $(P) H$ supply as well as ATP supply, and for some methylotrophs growth yields may be exclusively NAD(P)H-limited. Because of this NAD(P)H limitation, the concept of $Y_{\mathrm{ATP}}$ in methylotrophs should be used with extreme caution.
\end{abstract}

\section{INTRODUCTION}

The subject of this paper is the nature of those factors influencing growth yields of methylotrophic bacteria growing on methane, methanol, formaldehyde, formate and $N$-methyl compounds such as methylamine. It is generally true that molar growth yields $\left(Y_{\mathrm{S}}, Y_{\mathrm{O}_{2}}\right.$ and $\left.Y_{\mathrm{ATP}}\right)$ reflect the efficiency with which aerobic bacteria conserve energy via substrate-level and oxidative phosphorylation and subsequently use this energy for growth (see Farmer \& Jones, 1976; Stouthamer, I977). This generalization has been the basis of a number of calculations of predicted cell yields of methylotrophs (Harrison, Topiwala \& Hamer, I972; van Dijken \& Harder, I975; Harder \& van Dijken, 1976; Barnes et al., 1976), and these predictions have in turn been used to determine values for $\mathrm{P} / \mathrm{O}$ ratios based on measured cell yields (e.g. Goldberg et al., 1976).

In the present paper the important theoretical studies of van Dijken \& Harder (1975) have been modified and extended in response to the many recent developments in our knowledge of the biochemistry of methylotrophs which include elucidation of a variety of carbon assimilation pathways (Strøm, Ferenci \& Quayle, 1974; Colby \& Zatman, 1975; Cox \& Quayle, 1975; Anthony, 1975a), the understanding of the two different methane hydroxylase systems (Tonge, Harrison \& Higgins, 1977b; Colby, Dalton \& Whittenbury, 1975; Colby \& Dalton, I976; Colby, Stirling \& Dalton, 1977) and the relatively low P/O ratios associated with NADH oxidation indicated in some methylotrophs (Tonge, Drozd \& Higgins, I977a; O'Keeffe \& Anthony, I978; Anthony \& O'Keeffe, I977).

Perhaps the most important conclusions to be drawn from the calculations presented below is that the growth yields of some methylotrophs do not solely depend on the ATP yield from substrate oxidation; in particular, accurate prediction of $\mathrm{P} / \mathrm{O}$ ratios from cell yields measured on methane, methanol or $N$-methyl compounds is not always possible because these values are not directly related. This exception to the general rule derives in part from the fact that some methylotrophs are similar to autotrophs in that growth yield 
is markedly affected by the potential yield of reducing equivalents rather than by the ATP supply. This perhaps supports the entertaining suggestion of Whittenbury \& Kelly (1977) that methylotrophs are autotrophs.

\section{METHODS}

The majority of methods and assumptions used for the calculations below are derived from the work of van Dijken \& Harder (1975).

\section{General assumptions}

The formula used for cell material is $\mathrm{C}_{4} \mathrm{H}_{8} \mathrm{O}_{2} \mathrm{~N}$, which has been demonstrated in a number of methylotrophs (Maclennan et al., 197I ; Goldberg et al., 1976). It is assumed that the $Y_{\mathrm{ATP}}$ for assimilation of phosphoglycerate (PGA) is $10.5 \mathrm{~g}$ per mole of ATP, that the reductant for biosynthesis from PGA is $\mathrm{NAD}(\mathrm{P}) \mathrm{H}$, and that the nitrogen source is ammonia.

These assumptions lead to the following equation for assimilation of PGA into cell material:

$$
{ }_{4} \mathrm{PGA}+29 \mathrm{ATP}+5.5 \mathrm{NADH}+3 \mathrm{NH}_{3} \rightarrow 306 \mathrm{~g} \text { cell material }\left(\mathrm{C}_{4} \mathrm{H}_{8} \mathrm{O}_{2} \mathrm{~N}\right)_{3}+10 \mathrm{H}_{2} \mathrm{O}
$$

If a $Y_{\mathrm{ATP}}$ value of 14 (instead of 10.5 ) is chosen for cell synthesis from PGA, then equation (I) would require 22 ATP molecules but, because relatively large amounts of ATP and NADH are required for PGA formation from growth substrate in methylotrophs, this decrease $(24 \%$ ) in ATP requirement for cell formation has a disproportionately low effect on cell yields (increases of o to I4 \%).

If the alternative method recently suggested by Harder \& van Dijken (1976) is used to calculate the total ATP requirement for substrate assimilation then the overall formulae developed below will be almost unchanged except for bacteria using the serine pathway in which the ATP requirement will be greater. It is difficult, however, to determine how much greater this requirement would be because it is unclear at what stage in their calculation the implied assumption of reversed electron transport was incorporated (see below). A higher ATP requirement would lead to lower growth yields but only in those bacteria having low $\mathrm{P} / \mathrm{O}$ ratios for oxidation of methanol, methylamine and formaldehyde.

No specific allowance has been made for an energy requirement for active transport of growth substrates. Methane, methanol and formaldehyde being small uncharged molecules probably enter the bacteria by rapid diffusion down a concentration gradient and formate and methylamine may likewise enter as the uncharged species under appropriate $\mathrm{pH}$ conditions (D. T. O'Keeffe \& C. Anthony, unpublished results). However, if energy is required for transport of substrate then cell yields will be lower than predicted here in those bacteria which are not predominantly NAD(P)H-limited (see below).

All discussions below make the obvious assumption that the supply of carbon as such to the bacteria will also determine growth yields whether cells are also ATP- or NAD(P)H-limited.

\section{Assimilation pathways}

All pathways are represented as forming 4 molecules of PGA and as starting with carbon at the oxidation level of formaldehyde or $\mathrm{CO}_{2}$.

Ribulose bisphosphate pathway (RBP). This 'autotrophic' pathway has recently been shown to operate in Paracoccus denitrificans by Cox \& Quayle (1975):

$$
\mathrm{I}_{2} \mathrm{CO}_{2}+2 \mathrm{ONADH}+32 \mathrm{ATP} \rightarrow 4 \mathrm{PGA}
$$

Ribulose monophosphate pathway (RMP). Two of the known variants of this pathway are considered here: the fructose bisphosphate (FBP) variant and the Entner-Doudoroff (ED) variant (see Strøm et al., 1974). The sedoheptulose bisphosphate variant (Colby \& Zatman, 1975) leads to equations identical with those for the ED variant and so it will not be considered separately.

FBP variant: $12 \mathrm{HCHO}+4 \mathrm{H}_{2} \mathrm{O} \rightarrow 4 \mathrm{PGA}+4 \mathrm{NADH}$

ED variant: $12 \mathrm{HCHO}+4 \mathrm{H}_{2} \mathrm{O}+8 \mathrm{ATP} \rightarrow 4 \mathrm{PGA}+4 \mathrm{NADPH}$

Serine pathway $(S P)$. It is assumed that formation of malyl-CoA from malate uses I molecule of ATP regardless of mechanism. In the variant (icl $\left.{ }^{+}\right)$of the pathway involving isocitrate lyase, the oxidation of acetyl-CoA to glyoxylate yields NADH and the reduced flavoprotein of succinate dehydrogenase $\left(\mathrm{FPH}_{2}\right)$. Because NAD(P)H supply (rather than ATP supply) can be yield-limiting in some methylotrophs (see below) it is not valid to 'equate' $\mathrm{FPH}_{2}$ (+IATP) with NADH as was done in previous calculations (van Dijken \& Harder, 1975; Harder \& van Dijken, 1976). In the calculations below, the $\mathrm{P} / \mathrm{O}$ ratio for oxidation of $\mathrm{FPH}_{2}$ is usually taken as I less than the $\mathrm{P} / \mathrm{O}$ ratio for $\mathrm{NADH}$ oxidation. The (hypothetical) icl- variant 
considered here is the most extreme possibility where no reducing power is produced during oxidation of acetate to glyoxylate.

icl ${ }^{+}$variant: $8 \mathrm{HCHO}+8 \mathrm{NADH}+\mathrm{I}_{2} \mathrm{ATP}+4 \mathrm{CO}_{2} \rightarrow 4 \mathrm{PGA}+4 \mathrm{FPH}_{2}$ icl- variant: $8 \mathrm{HCHO}+12 \mathrm{NADH}+\mathrm{I} 2 \mathrm{ATP}+4 \mathrm{CO}_{2}+4 \mathrm{O}_{2} \rightarrow 4 \mathrm{PGA}+8 \mathrm{H}_{2} \mathrm{O}$

Comparison of the RMP equations with the SP equations shows that provision of NADH is relatively more important during growth by the serine pathway; it is clear that this is partly related to the involvement of $\mathrm{CO}_{2}$ in the serine pathway.

Assimilation of formaldehyde and $\mathrm{CO}_{2}$ into cell material. The equations for assimilation of $\mathrm{HCHO}$ and $\mathrm{CO}_{2}$ into PGA can be combined with the equation for assimilation of PGA into cell material to give assimilation equations for formaldehyde and $\mathrm{CO}_{2}$ into cell material.

Ribulose bisphosphate pathway:

$$
\mathrm{I} 2 \mathrm{CO}_{2}+25 \cdot 5 \mathrm{NADH}+6 \mathrm{IATP}+3 \mathrm{NH}_{3} \rightarrow 306 \mathrm{~g} \text { cell }+\mathrm{I} 8 \mathrm{H}_{2} \mathrm{O}
$$

Ribulose monophosphate pathway:

FBP variant:

$$
\mathrm{I} 2 \mathrm{HCHO}+\mathrm{I} \cdot 5 \mathrm{NADH}+29 \mathrm{ATP}+3 \mathrm{NH}_{3} \rightarrow 306 \mathrm{~g} \text { cell }+6 \mathrm{H}_{2} \mathrm{O}
$$

ED variant:

$\mathrm{I} 2 \mathrm{HCHO}+\mathrm{I} \cdot 5 \mathrm{NADH}+37 \mathrm{ATP}+3 \mathrm{NH}_{3} \rightarrow 306 \mathrm{~g}$ cell $+6 \mathrm{H}_{2} \mathrm{O}$

Serine pathway:

icl $^{+}$variant: $8 \mathrm{HCHO}+{ }_{1} 3.5 \mathrm{NADH}+4 \mathrm{IATP}+4 \mathrm{CO}_{2}+{ }_{3} \mathrm{NH}_{3} \rightarrow 306 \mathrm{~g}$ cell $+4 \mathrm{FPH}_{2}+\mathrm{IOH}_{2} \mathrm{O}$

icl- variant: $8 \mathrm{HCHO}+17 \cdot 5 \mathrm{NADH}+4 \mathrm{IATP}+4 \mathrm{CO}_{2}+3 \mathrm{NH}_{3}+4 \mathrm{O}_{2} \rightarrow 306 \mathrm{~g}$ cell $+18 \mathrm{H}_{2} \mathrm{O}$

Metabolism of $\mathrm{C}_{1}$ substrates for provision of $\mathrm{CO}_{2}, \mathrm{NADH}$ and $\mathrm{ATP}$

To express the above equations solely in terms of substrate carbon, cell material, oxygen and $\mathrm{CO}_{2}$, the various routes for initial metabolism of growth substrates must be considered. The general pathway for oxidation of $\mathrm{C}_{1}$ compounds is:

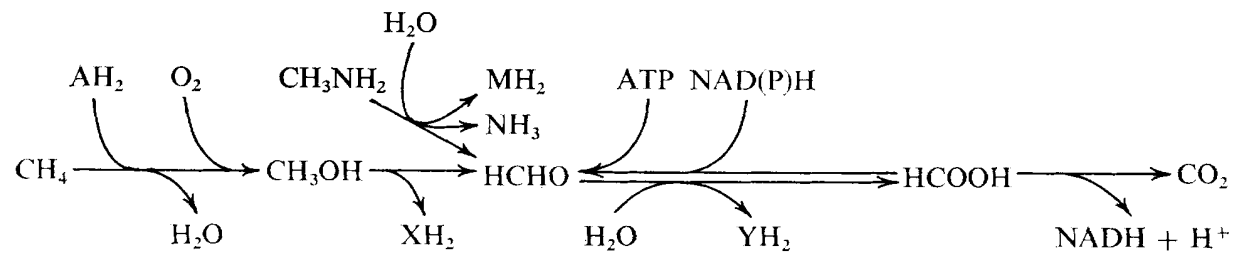

The symbol $\mathrm{AH}_{2}$ indicates either $\mathrm{XH}_{2}$ or $\mathrm{NADH}+\mathrm{H}^{+} ; \mathrm{XH}_{2}$ is reduced methanol dehydrogenase; $\mathrm{MH}_{2}$ is reduced methylamine dehydrogenase; $\mathrm{YH}_{2}$ is the product of formaldehyde oxidation and is sometimes NADH (for convenience it is referred to as $\mathrm{YH}_{2}$ even w'.en this is known to be NADH). In all methylotrophs studied, the oxidation of formate to $\mathrm{CO}_{2}$ yields $\mathrm{NADH}$. Little is known about the $\mathrm{P} / \mathrm{O}$ ratios occurring during oxidation of $\mathrm{XH}_{2}, \mathrm{MH}_{2}, \mathrm{YH}_{2}$ or $\mathrm{NADH}$; recent reports suggest that a $\mathrm{P} / \mathrm{O}$ ratio of $\mathrm{I}$ is likely for these oxidations in methane-grown Methylosinus trichosporium (Tonge et al., 1977a) whereas $\mathrm{P} / \mathrm{O}$ ratios of at least 2 may be possible in the facultative methylotroph Pseudomonas AmI (O'Keeffe \& Anthony, 1977, 1978; Anthony \& O'Keeffe, 1977).

Methane oxidation. The first step in this hydroxylation process is probably always catalysed by a mixed function oxygenase requiring a reductant $\left(\mathrm{AH}_{2}\right)$ and molecular oxygen. Two such systems have now been described: one system (system $\mathrm{N}$ ) requires $\mathrm{NAD}(\mathrm{P}) \mathrm{H}$ (Colby et al., 1975) and the other (system $\mathrm{M}$ ) requires methanol dehydrogenase $\left(\mathrm{XH}_{2}\right)$ and cytochrome $c$ (Tonge et al., 1977b). When the $\mathrm{N}$ system operates, the provision of NADH for biosynthesis is only possible when formaldehyde oxidation yields 2 molecules of $\mathrm{NADH}$; this may be produced either directly by dehydrogenases or indirectly by the cyclic route not involving formate dehydrogenase (see below).

Methanol oxidation. This is mediated by a methanol dehydrogenase (MDH) whose function is independent of $\mathrm{NAD}^{+}$and which is possibly a pteridoprotein (Anthony \& Zatman, 1967). The dehydrogenase interacts (maybe indirectly) at the level of cytochrome $c$ with the electron transport system (Anthony, I975 $b$; Widdowson \& Anthony, 1975); it is unlikely to yield more than 2 moles of ATP per mole of methanol oxidized. As mentioned above, the MDH (coupled with cytochrome $c$ ) acts as the reducing agent in some methane hydroxylation systems (M systems). In bacteria with these systems, during growth on methane the $\mathrm{MDH}$ is only reoxidized (indirectly) by oxygen in the methane mono-oxygenase reaction and not by an oxidase; in such bacteria the MDH may not be coupled to oxygen through a typical cytochrome system terminating in a cytochrome oxidase; in this case growth might not occur on methanol unless the cytochrome ' is autoxidizable. 
Oxidation of $\mathrm{N}$-methyl compounds. Almost all those methylotrophs unable to grow on methane are capable of growth on methylamine, and often also on dimethylamine and trimethylamine; some also grow on trimethylamine $N$-oxide and tetramethylammonium salts (see Anthony, 1975a). There is a variety of oxidation routes for these substrates and so a complete analysis of all possibilities will not be presented here. Each methyl group of an $N$-methyl compound is oxidized to I molecule of formaldehyde. Some of these oxidations are catalysed by dehydrogenases (not $\mathrm{NAD}(\mathrm{P})^{+}$-linked) and produce reducing equivalents which may be coupled to ATP generation, while others are catalysed by mono-oxygenases requiring $N A D(P) H$ and molecular oxygen (see Large, 197I). There are two systems which may be involved in methylamine oxidation to formaldehyde but neither yields $\mathrm{NAD}(\mathrm{P}) \mathrm{H}$.

Formaldehyde oxidation. A number of different enzymes may be involved in formaldehyde oxidation (see Anthony, 1975a), including NAD+-linked dehydrogenases, flavoprotein dehydrogenases (probably) and methanol dehydrogenase. Some, perhaps all, RMP-bacteria oxidize formaldehyde to $\mathrm{CO}_{2}$ by a cyclic system producing 2 molecules of $\mathrm{NAD}(\mathrm{P}) \mathrm{H}$. This is energetically equivalent to oxidation by $\mathrm{NAD}^{+}$-linked dehydrogenase to formate followed by further oxidation to $\mathrm{CO}_{2}$ (Strøm et al., 1974; Colby \& Zatman, 1975). This route enables bacteria to oxidize $\mathrm{C}_{1}$ compounds completely to $\mathrm{CO}_{2}$ in the absence of a formate dehydrogenase. Another cyclic route that may achieve this has been proposed for Pseudomonas Ma growing by way of the serine pathway (Newaz \& Hersh, 1975). The products of formaldehyde oxidation to $\mathrm{CO}_{2}$ in this case are 1 molecule of NADH plus the reduced flavoprotein of succinate dehydrogenase.

Formate oxidation. All methylotrophic bacteria able to oxidize formate do so in a reaction catalysed by a soluble NAD+-linked dehydrogenase. Reduction to formaldehyde is assumed to involve methenyltetrahydrofolate formation, which requires ATP.

\section{Equations for estimation of cell yields, $Y_{\mathrm{S}}, Y_{\mathrm{O}_{2}}$ and $Y_{\mathrm{CO}_{2}}$ values}

These equations are derived from those given above for assimilation of formaldehyde and $\mathrm{CO}_{2}$, and for production of formaldehyde, $\mathrm{CO}_{2}$ and $\mathrm{NADH}$ from growth substrate. For simplicity, $\mathrm{NAD}^{+}, \mathrm{ADP}$, phosphate, ammonia, water and protons are omitted from the equations. For assimilation of methane, methanol, formaldehyde and $\mathrm{N}$-methyl compounds, the equations will be different if formaldehyde oxidation to $\mathrm{CO}_{2}$ yields 2 molecules of NADH because relatively less substrate has to be oxidized to provide NADH. Unless otherwise stated, the formulations below assume that only formate oxidation gives rise to NADH; where relevant, $\mathrm{YH}_{2}$ may be equated with $\mathrm{NADH}$.

For prediction of cell yields, the ATP in these equations is replaced by the amount of substrate whose oxidation is sufficient to satisfy the ATP requirement remaining after subtraction of the ATP generated by oxidation of any reducing equivalents in the right-hand side of the equation. By including the oxygen requirement for these oxidations, and the $\mathrm{CO}_{2}$ produced, $Y_{\mathrm{S}}, Y_{\mathrm{O}_{2}}$ and $Y_{\mathrm{CO}_{2}}$ may be calculated. An alternative expression of the $Y_{\mathrm{CO}_{2}}$ is given by the percentage of substrate carbon being oxidized completely to $\mathrm{CO}_{2}$; this is the value given in the tables of predictions and is calculated by dividing the $Y_{\mathrm{S}}$ values by the $Y_{\mathrm{CO}_{2}}$ values.

\section{Assimilation of methane.}

(i) NADH-linked methane hydroxylase system ( $\mathrm{N}$ system) $\left(\mathrm{YH}_{2}\right.$ is $\left.\mathrm{NADH}\right)$

$$
\begin{array}{ll}
\text { RMP (FBP variant): } & 25 \cdot 5 \mathrm{CH}_{4}+25 \cdot 5 \mathrm{O}_{2}+29 \mathrm{ATP} \rightarrow 306 \mathrm{~g} \text { cell }+\mathrm{I} 3 \cdot 5 \mathrm{CO}_{2}+25 \cdot 5 \mathrm{XH}_{2} \\
\text { RMP (ED variant): } & 25 \cdot 5 \mathrm{CH}_{4}+25 \cdot 5 \mathrm{O}_{2}+37 \mathrm{ATP} \rightarrow 306 \mathrm{~g} \text { cell }+\mathrm{I} 3 \cdot 5 \mathrm{CO}_{2}+25 \cdot 5 \mathrm{XH}_{2} \\
\text { SP (icl+ variant): } & 29 \cdot 5 \mathrm{CH}_{4}+29 \cdot 5 \mathrm{O}_{2}+4 \mathrm{I} \mathrm{ATP} \rightarrow 306 \mathrm{~g} \text { cell }+\mathrm{I} 7 \cdot 5 \mathrm{CO}_{2}+29 \cdot 5 \mathrm{XH}_{2}+4 \mathrm{FPH}_{2} \\
\text { SP (icl- variant): } & 33 \cdot 5 \mathrm{CH}_{4}+37 \cdot 5 \mathrm{O}_{2}+4 \mathrm{IATP} \rightarrow 306 \mathrm{~g} \text { cell }+2 \mathrm{I} \cdot 5 \mathrm{CO}_{2}+33 \cdot 5 \mathrm{XH}_{2}
\end{array}
$$

(ii) MDH-linked methane hydroxylase system (M system)

$$
\begin{aligned}
& \text { RMP (FBP variant): } \\
& \text { RMP (ED variant): } \\
& \text { SP (icl' variant): } \\
& \text { SP (icl- variant): }
\end{aligned}
$$

Assimilation of methanol.

$\mathrm{RBP}\left(\mathrm{YH}_{2}\right.$ is not $\left.\mathrm{NADH}\right)$ :

$$
25 \cdot 5 \mathrm{CH}_{3} \mathrm{OH}+61 \mathrm{ATP} \quad \rightarrow 306 \mathrm{~g} \text { cell }+13 \cdot 5 \mathrm{CO}_{2}+25 \cdot 5 \mathrm{XH}_{2}+25 \cdot 5 \mathrm{YH}_{2}
$$

$\mathrm{RBP}\left(\mathrm{YH}_{2}\right.$ is $\left.\mathrm{NADH}\right)$ :

$$
13 \cdot 5 \mathrm{CH}_{3} \mathrm{OH}+6 \mathrm{IATP} \quad \rightarrow 306 \mathrm{~g} \mathrm{cell}+\mathrm{I} \cdot 5 \mathrm{CO}_{2}+\mathrm{I} 3 \cdot 5 \mathrm{XH}_{2}
$$


RMP (FBP variant):

$$
\text { I } 3.5 \mathrm{CH}_{3} \mathrm{OH}+29 \mathrm{ATP} \quad \rightarrow 306 \mathrm{~g} \mathrm{cell}+\mathrm{I} \cdot 5 \mathrm{CO}_{2}+\mathrm{I} 3 \cdot 5 \mathrm{XH}_{2}+\mathrm{I} \cdot 5 \mathrm{YH}_{2}
$$

RMP (ED variant):

$\mathrm{I} 3.5 \mathrm{CH}_{3} \mathrm{OH}+37 \mathrm{ATP} \quad \rightarrow 306 \mathrm{~g} \mathrm{cell}+\mathrm{I} \cdot 5 \mathrm{CO}_{2}+\mathrm{I} 3.5 \mathrm{XH}_{2}+\mathrm{I} \cdot 5 \mathrm{YH}_{2}$

SP (icl ${ }^{+}$variant):

$2 \mathrm{I} \cdot 5 \mathrm{CH}_{3} \mathrm{OH}+4 \mathrm{IATP} \rightarrow 306 \mathrm{~g} \mathrm{cell}+9 \cdot 5 \mathrm{CO}_{2}+2 \mathrm{I} \cdot 5 \mathrm{XH}_{2}+\mathrm{I} 3 \cdot 5 \mathrm{YH}_{2}+4 \mathrm{FPH}_{2}$

SP (icl- variant):

$25 \cdot 5 \mathrm{CH}_{3} \mathrm{OH}+4 \mathrm{IATP}+4 \mathrm{O}_{2} \rightarrow 306 \mathrm{~g}$ cell $+\mathrm{I} 3 \cdot 5 \mathrm{CO}_{2}+25 \cdot 5 \mathrm{XH}_{2}+\mathrm{I}_{7} \cdot 5 \mathrm{YH}_{2}$

$\mathrm{SP}\left(\mathrm{icl}^{+}, \mathrm{YH}_{2}\right.$ is $\left.\mathrm{NADH}\right)$ :

I $4 \cdot 3 \mathrm{CH}_{3} \mathrm{OH}+4 \mathrm{IATP} \quad \rightarrow 306 \mathrm{~g} \mathrm{cell}+2 \cdot 3 \mathrm{CO}_{2}+\mathrm{I} 4 \cdot 3 \mathrm{XH}_{2}+4 \mathrm{FPH}_{2}$

Assimilation of formaldehyde.

RMP (FBP variant): $13.5 \mathrm{HCHO}+29 \mathrm{ATP} \quad \rightarrow 306 \mathrm{~g} \mathrm{cell}+\mathrm{I} \cdot 5 \mathrm{CO}_{2}+\mathrm{I} \cdot 5 \mathrm{YH}_{2}$

$\mathrm{RMP}\left(\mathrm{ED}\right.$ variant): $\mathrm{I} 3 \cdot 5 \mathrm{HCHO}+37 \mathrm{ATP} \rightarrow 306 \mathrm{~g} \mathrm{cell}+\mathrm{I} \cdot 5 \mathrm{CO}_{2}+\mathrm{I} \cdot 5 \mathrm{YH}_{2}$

$\mathrm{SP}\left(\mathrm{icl}^{+}\right.$variant $): \quad 2 \mathrm{I} \cdot 5 \mathrm{HCHO}+4 \mathrm{IATP} \rightarrow 306 \mathrm{~g} \mathrm{cell}+9.5 \mathrm{CO}_{2}+13.5 \mathrm{YH}_{2}+4 \mathrm{FPH}_{2}$

$\mathrm{SP}$ (icl- variant): $\quad 25 \cdot 5 \mathrm{HCHO}+4 \mathrm{I} \mathrm{ATP}+4 \mathrm{O}_{2} \rightarrow 306 \mathrm{~g}$ cell $+\mathrm{I} 3 \cdot 5 \mathrm{CO}_{2}+\mathrm{I} 7 \cdot 5 \mathrm{YH}_{2}$

Assimilation of formate.

RMP (FBP variant): $25 \cdot 5 \mathrm{HCOOH}+4 \mathrm{IATP} \quad \rightarrow 306 \mathrm{~g}$ cell $+\mathrm{I} 3 \cdot 5 \mathrm{CO}_{2}$

RMP (ED variant): $25.5 \mathrm{HCOOH}+49 \mathrm{ATP} \quad \rightarrow 306 \mathrm{~g}$ cell $+13.5 \mathrm{CO}_{2}$

SP (icl ${ }^{+}$variant): $\quad 29 \cdot 5 \mathrm{HCOOH}+49 \mathrm{ATP} \quad \rightarrow 306 \mathrm{~g} \mathrm{cell}+\mathrm{I} 7 \cdot 5 \mathrm{CO}_{2}+4 \mathrm{FPH}_{2}$

$\mathrm{SP}$ (icl- variant): $\quad 33 \cdot 5 \mathrm{HCOOH}+49 \mathrm{ATP}+4 \mathrm{O}_{2} \rightarrow 306 \mathrm{~g}$ cell $+2 \mathrm{I} \cdot 5 \mathrm{CO}_{2}$

Assimilation of methylamine. The equations are the same as those for methanol except that $\mathrm{XH}_{2}$ should be replaced by $\mathrm{MH}_{2}$.

Assimilation of dimethylamine and trimethylamine. When all oxidation steps are catalysed by dehydrogenases (not $\mathrm{NAD}^{+}$-linked), equations for assimilation are essentially similar to those for methylamine. Equations for dimethylamine (with one hydroxylation step) and trimethylamine (with two hydroxylation steps) are given below for bacteria with the ribulose monophosphate pathway (FBP variant) and with the serine pathway $\left(\mathrm{icl}^{+}\right.$variant).

\section{Dimethylamine}

$\mathrm{RMP}\left(\mathrm{YH}_{2}\right.$ is not $\left.\mathrm{NADH}\right)$ :

$13 \cdot 5\left(\mathrm{CH}_{3}\right)_{2} \mathrm{NH}+\mathrm{I} 3 \cdot 5 \mathrm{O}_{2}+29 \mathrm{ATP} \rightarrow 306 \mathrm{~g}$ cell $+\mathrm{I}_{5} \mathrm{CO}_{2}+\mathrm{I} 3 \cdot 5 \mathrm{MH}_{2}+{ }_{15} \mathrm{YH}_{2}$

$\mathrm{SP}\left(\mathrm{YH}_{2}\right.$ is not $\left.\mathrm{NADH}\right)$ :

$2 \mathrm{r} \cdot 5\left(\mathrm{CH}_{3}\right)_{2} \mathrm{NH}+2 \mathrm{I} \cdot 5 \mathrm{O}_{2}+4 \mathrm{IATP} \rightarrow 306 \mathrm{~g}$ cell $+3 \mathrm{ICO}_{2}+2 \mathrm{I} \cdot 5 \mathrm{MH}_{2}+35 \mathrm{YH}_{2}+4 \mathrm{FPH}_{2}$

RMP ( $\mathrm{YH}_{2}$ is $\left.\mathrm{NADH}\right)$ :

$6 \cdot 5\left(\mathrm{CH}_{3}\right)_{2} \mathrm{NH}+6 \cdot 5 \mathrm{O}_{2}+29 \mathrm{ATP} \rightarrow 306 \mathrm{~g}$ cell $+\mathrm{CO}_{2}+\mathrm{I} 2 \cdot 5 \mathrm{MH}_{2}$

$\mathrm{SP}\left(\mathrm{YH}_{2}\right.$ is $\left.\mathrm{NADH}\right)$ :

$$
\mathrm{IO}\left(\mathrm{CH}_{3}\right)_{2} \mathrm{NH}+\mathrm{IOO}_{2}+4 \mathrm{IATP} \rightarrow 306 \mathrm{~g} \mathrm{cell}+8 \mathrm{CO}_{2}+\mathrm{IOMH}_{2}+4 \mathrm{FPH}_{2}
$$

\section{Trimethylamine}

RMP ( $\mathrm{YH}_{2}$ is not $\left.\mathrm{NADH}\right)$ :

$$
{ }_{13} \cdot 5\left(\mathrm{CH}_{3}\right)_{3} \mathrm{~N}+27 \mathrm{O}_{2}+29 \mathrm{ATP} \rightarrow 306 \mathrm{~g} \mathrm{cell}+28 \cdot 5 \mathrm{CO}_{2}+13 \cdot 5 \mathrm{MH}_{2}+28 \cdot 5 \mathrm{YH}_{2}
$$

$\mathrm{SP}\left(\mathrm{YH}_{2}\right.$ is not $\left.\mathrm{NADH}\right)$ :

$$
2 \mathrm{I} \cdot 5\left(\mathrm{CH}_{3}\right)_{3} \mathrm{~N}+43 \mathrm{O}_{2}+4 \mathrm{IATP} \rightarrow 306 \mathrm{~g} \mathrm{cell}+52 \cdot 5 \mathrm{CO}_{2}+2 \mathrm{I} \cdot 5 \mathrm{MH}_{2}+56 \cdot 5 \mathrm{YH}_{2}+4 \mathrm{FPH}_{2}
$$

RMP ( $\mathrm{YH}_{2}$ is $\left.\mathrm{NADH}\right)$ :

$$
6 \cdot 5\left(\mathrm{CH}_{3}\right)_{3} \mathrm{~N}+\mathrm{I}_{3} \mathrm{O}_{2}+29 \mathrm{ATP} \rightarrow 306 \mathrm{~g} \mathrm{cell}+7 \cdot 5 \mathrm{CO}_{2}+6 \cdot 5 \mathrm{MH}_{2}
$$

$\mathrm{SP}\left(\mathrm{YH}_{2}\right.$ is $\left.\mathrm{NADH}\right)$ :

$$
7 \cdot 6\left(\mathrm{CH}_{3}\right)_{3} \mathrm{~N}+\mathrm{I}_{5} \mathrm{O}_{2}+4 \mathrm{IATP} \rightarrow 306 \mathrm{~g} \mathrm{cell}+\mathrm{I} 4 \cdot 5 \mathrm{CO}_{2}+7 \cdot 5 \mathrm{MH}_{2}+4 \mathrm{FPH}_{2}
$$




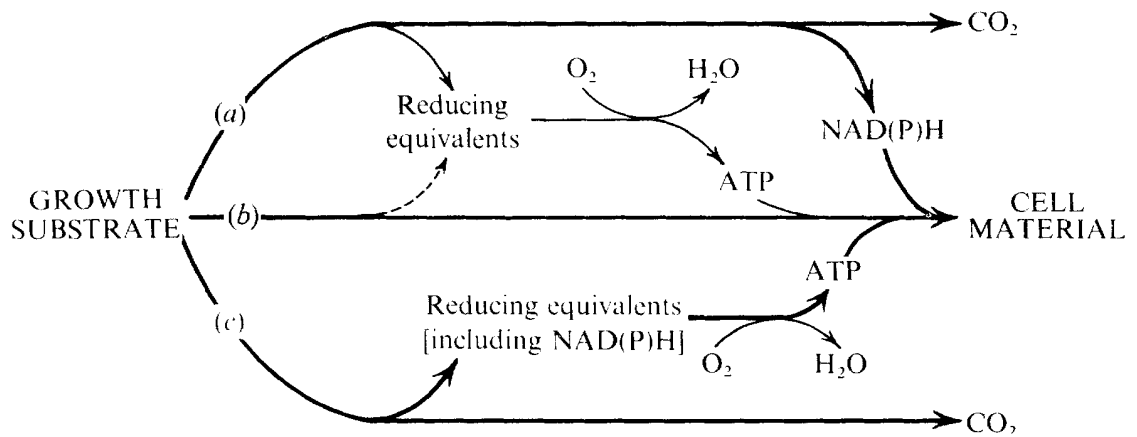

Fig. I. The relationship between NAD $(\mathrm{P}) \mathrm{H}$ production, oxygen consumption, ATP synthesis and production of cell material illustrating the conditions for $\mathrm{NAD}(\mathrm{P}) \mathrm{H}$ limitation of growth yield. The growth substrate (carbon source) is metabolized to produce: $(a) \mathrm{NAD}(\mathrm{P}) \mathrm{H} ;(b)$ cell material; (c) ATP. The first condition for NAD $(P) H$ limitation is that there should be a high $\mathrm{NAD}(\mathrm{P}) \mathrm{H}$ requirement for assimilation of growth substrate into cell material; a measure of this requirement is given by $a / b$. The second condition is that oxidation of substrate to supply carbon precursors $(b)$ and $\mathrm{NAD}(\mathrm{P}) \mathrm{H}(a)$ for biosynthesis should also produce further additional reducing equivalents [other than $\mathrm{NAD}(\mathrm{P}) \mathrm{H}$ ], whose oxidation by molecular oxygen may also be coupled to ATP generation. An indication of the overall extent of $\mathrm{NAD}(\mathrm{P}) \mathrm{H}$ limitation is given by $(a+b) / c$. In bacteria which are exclusively $\mathrm{NAD}(\mathrm{P}) \mathrm{H}$-limited, oxidation of growth substrate exclusively for ATP production $(c)$ is unnecessary.

\section{RESULTS AND DISCUSSION}

Tables $\mathrm{I}$ to 4 show predictions of the effect on cell yields $\left(Y_{\mathrm{s}}, Y_{\mathrm{O}_{2}}\right.$ and $\left.Y_{\mathrm{CO}_{2}}\right)$ of the three main assimilation pathways, of the nature of the oxidation pathways, and of the $\mathrm{P} / \mathrm{O}$ ratios for the oxidation of substrate to $\mathrm{CO}_{2}$. The conclusions are, of course, reflexions of the overall equations for substrate oxidation and assimilation developed in Methods. Predicted yields for variants of the main pathways are discussed below although for convenience they are not included in the Tables. The predicted molar growth yields for methylamine are identical with those for methanol. Equations are developed in Methods for assimilation of dimethylamine and trimethylamine by the alternative routes involving mono-oxygenases; because of the considerable variety of these routes, full tables of predictions have not been included but general points relating to the effect of $\mathrm{P} / \mathrm{O}$ ratios on cell yields with these substrates are discussed in a separate section below.

\section{The concept of $N A D(P) H$ limitation of growth yields in methylotrophs}

This section introduces the concept that the growth yields of some methylotrophs are determined partly or exclusively by the supply of NAD $(\mathrm{P}) \mathrm{H}$ and not predominantly by the ATP supply as is the case in most heterotrophs.

The growth yield of bacteria growing on a single source of carbon plus energy is mainly determined by the efficiency of assimilation of the carbon precursors for biosynthesis and by the supply of the necessary ATP and NAD $(P) H$ required for this assimilation. The conversion of most growth substrates to precursors for biosynthesis (e.g. PGA) requires very little, if any, $\mathrm{NAD}(\mathrm{P}) \mathrm{H}$. Very high proportions of most growth substrates are converted to cell carbon or oxidized to $\mathrm{CO}_{2}$ for ATP production, and a very low proportion of growth substrate is oxidized to $\mathrm{CO}_{2}$ primarily to provide $\mathrm{NAD}(\mathrm{P}) \mathrm{H}$ for biosynthesis (thus in Fig. I, $b$ and $c$ are large and $a$ is small). The molar growth yields of most typical heterotrophs are thus predominantly determined by the ATP supply which, in turn, is governed by the $\mathrm{P} / \mathrm{O}$ ratio. When, by contrast, there is a high $\mathrm{NAD}(\mathrm{P}) \mathrm{H}$ requirement for assimilation of growth substrate into cell material, then growth will be either exclusively NAD(P)Hlimited or it will be determined by both NAD(P)H and ATP supply; this high NAD(P)H requirement occurs in autotrophs and most methylotrophs but in very few heterotrophs. 


\section{Table $\mathrm{I}$. The predicted effect of variations in $P / O$ ratios on cell yields during growth on methane}

The $\mathbf{P} / \mathrm{O}$ ratios are the numbers of ATP molecules produced per atom of oxygen during oxidation of methanol to formaldehyde $(\mathrm{X})$, formaldehyde to formate $(\mathrm{Y})$ and formate to $\mathrm{CO}_{2}(\mathrm{Z})$, this last step being catalysed by NAD+-linked dehydrogenase. In bacteria with the NAD(P)H-linked methane hydroxylation system ( $\mathrm{N}$ system), formaldehyde oxidation must be $\mathrm{NAD}^{+}$-linked $\left(\mathrm{YH}_{2}=\right.$ NADH). In bacteria with the methanol dehydrogenase/cytochrome $c$-linked system (M system), formaldehyde may be oxidized by any sort of dehydrogenase; the presence of methanol 'oxidase' coupled to ATP generation is only essential if formaldehyde is oxidized by methanol dehydrogenase. When NADH 'oxidase' is absent, the yield of SP-bacteria may be markedly influenced by the $\mathrm{P} / \mathrm{O}$ ratio for succinate oxidation to fumarate; the range of values is therefore given below. For SP-bacteria with an M system for methane hydroxylation a slightly higher yield is sometimes predicted when 2 moles of NADH are produced per mole of formaldehyde oxidized; this value is marked by an asterisk $\left({ }^{*}\right) . Y_{\mathrm{S}}, Y_{\mathrm{O}_{2}}$ and $Y_{\mathrm{CO}_{2}}$ are molar growth yields with respect to carbon substrate, oxygen and $\mathrm{CO}_{2} ; Y_{\mathrm{sg}}$ is the yield (g dry weight bacteria) per $\mathrm{g}$ substrate. $\% \mathrm{CO}_{2}$ is the percentage of carbon substrate oxidized completely to $\mathrm{CO}_{2}\left(=100 Y_{\mathrm{s}} / Y_{\mathrm{CO}_{2}}\right)$.

\begin{tabular}{|c|c|c|c|c|c|c|c|c|c|c|c|c|}
\hline \multicolumn{3}{|c|}{$\mathrm{P} / \mathrm{O}$ ratio } & \multicolumn{5}{|c|}{ RMP-bacteria (FBP variant) } & \multicolumn{5}{|c|}{ SP-bacteria (icl ${ }^{+}$variant) } \\
\hline $\mathrm{X}$ & $\mathrm{Y}$ & $\mathrm{Z}$ & $Y_{\mathrm{sg}}$ & $Y_{\mathrm{S}}$ & $Y_{\mathrm{O}_{2}}$ & $Y_{\mathrm{CO}_{2}}$ & $\% \mathrm{CO}_{2}$ & $Y_{\mathrm{sg}}$ & $Y_{\mathrm{S}}$ & $Y_{\mathrm{O}_{2}}$ & $Y_{\mathrm{CO}_{2}}$ & $\% \mathrm{CO}_{2}$ \\
\hline \multicolumn{13}{|c|}{ Bacteria with the $N$ hydroxylation system for methane } \\
\hline 2 & 3 & & $0 \cdot 75$ & $12 \cdot 0$ & $8 \cdot 0$ & $22 \cdot 7$ & 54 & 0.65 & 10.4 & $6 \cdot 7$ & $17 \cdot 5$ & 60 \\
\hline 1 & 3 & & 0.72 & $11 \cdot 6$ & $7 \cdot 5$ & $21 \cdot \mathrm{I}$ & 55 & 0.63 & $10 \cdot 0$ & $6 \cdot 4$ & $16 \cdot 5$ & 61 \\
\hline 1 & 2 & & 0.72 & $11 \cdot 6$ & $7 \cdot 5$ & $2 I \cdot I$ & 55 & 0.60 & $9 \cdot 6$ & 6.0 & $15 \cdot 3$ & 67 \\
\hline 1 & 1 & & 0.70 & I I I I & $7 \cdot 2$ & $19 \cdot 7$ & 56 & 0.54 & $8 \cdot 7$ & $5 \cdot 3$ & $13 \cdot 0$ & 64 \\
\hline 2 & o & & 0.75 & $12 \cdot 0$ & $8 \cdot 0$ & $22 \cdot 7$ & 53 & 0.65 & 10.4 & $6 \cdot 7$ & $17 \cdot 5$ & 59 \\
\hline 1 & 0 & & 0.66 & $10 \cdot 6$ & $6 \cdot 7$ & $18 \cdot 0$ & 59 & $0.47-0.58$ & $7 \cdot 5-9 \cdot 3$ & $4 \cdot 4$ & $10 \cdot 6$ & $64-70$ \\
\hline o & 3 & & 0.54 & $8 \cdot 6$ & $5 \cdot 2$ & $13 \cdot 0$ & 66 & 0.47 & $7 \cdot 6$ & $4 \cdot 5$ & $10 \cdot 7$ & 70 \\
\hline 0 & 2 & & 0.48 & $7 \cdot 7$ & $4 \cdot 5$ & 10.9 & 71 & 0.40 & $6 \cdot 4$ & $3 \cdot 7$ & $8 \cdot 5$ & 76 \\
\hline 0 & I & & 0.35 & $5 \cdot 6$ & $3 \cdot 2$ & $7 \cdot 2$ & 78 & 0.27 & $4 \cdot 3$ & $2 \cdot 4$ & $5 \cdot 2$ & 80 \\
\hline \multicolumn{13}{|c|}{ Bacteria with the $M$ hydroxylation system for methane } \\
\hline & $3^{*}$ & 3 & & & & & & $0.94 *$ & $15 \cdot 1$ & 10.9 & $37 \cdot 1$ & 42 \\
\hline & 3 & 3 & $I \cdot 09$ & $17 \cdot 5$ & $13 \cdot 6$ & 56 & $3 I$ & 0.89 & $14 \cdot 3$ & $10 \cdot 0$ & 32 & 42 \\
\hline & 2 & 3 & $\mathrm{I} \cdot 03$ & $16 \cdot 5$ & 12.5 & 47 & 35 & 0.85 & $13 \cdot 6$ & $9 \cdot 4$ & 29 & $4 I$ \\
\hline & 2 & 2 & 0.96 & $15 \cdot 3$ & $I I \cdot I$ & 38 & 40 & 0.80 & $13 \cdot 0$ & $8 \cdot 9$ & 27 & 50 \\
\hline & I & 3 & 0.93 & 14.9 & $10 \cdot 7$ & 36 & $4 I$ & 0.72 & $\mathrm{II} \cdot 6$ & $7 \cdot 6$ & $2 I$ & 55 \\
\hline & 1 & 2 & 0.85 & $13 \cdot 6$ & $9 \cdot 4$ & 29 & 47 & 0.69 & $I I \cdot I$ & $7 \cdot 2$ & $19 \cdot 7$ & 57 \\
\hline & $I$ & I & 0.70 & $I I \cdot I$ & $7 \cdot 2$ & 20 & 56 & 0.54 & $8 \cdot 6$ & $5 \cdot 2$ & 13.0 & 66 \\
\hline & 2 & 0 & 0.68 & $10 \cdot 9$ & $7 \cdot 6$ & $2 \mathrm{I}$ & 57 & $0.67-0.78$ & $10 \cdot 7-12 \cdot 5$ & $6 \cdot 9$ & 18.6 & $5 \mathrm{I}-58$ \\
\hline & 1 & 0 & 0.45 & $7 \cdot 2$ & $4 \cdot 4$ & $10 \cdot 6$ & 72 & $0.38-0.47$ & $6 \cdot 3-7 \cdot 5$ & $3 \cdot 6$ & $8 \cdot 3$ & $7 I-76$ \\
\hline & 0 & 3 & $0.8 \mathrm{I}$ & 13.0 & $8 \cdot 9$ & 27 & 49 & 0.59 & $9 \cdot 4$ & $5 \cdot 8$ & 14.9 & 64 \\
\hline & 0 & 2 & 0.68 & 10.9 & $7 \cdot 0$ & I9 & 57 & 0.48 & $7 \cdot 7$ & $4 \cdot 5$ & 10.9 & 70 \\
\hline & 0 & I & 0.45 & $7 \cdot 2$ & $4 \cdot 3$ & IO & 72 & 0.31 & $4 \cdot 9$ & $2 \cdot 7$ & $6 \cdot 1$ & 80 \\
\hline
\end{tabular}

If the oxidation of growth substrate produces reducing equivalents predominantly in the form of $\mathrm{NAD}(\mathrm{P}) \mathrm{H}$ then the high requirement for reducing power may be expressed as a carbon or ATP requirement in equations for the prediction of cell yield, and the usual relationships between $\mathrm{P} / \mathrm{O}$ ratio, $Y_{\mathrm{O}_{2}}$ and $Y_{\mathrm{ATP}}$ values will be valid. This is also true if reversed electron transport occurs; in this case the capacity to generate $\mathrm{NAD}(\mathrm{P}) \mathrm{H}$ is directly related to the protonmotive force set up across the cell membrane by ATP hydrolysis or by electron transport from electron donors to oxygen (see Jones, 1977; Aleem, 1977).

A measure of the NAD(P)H requirement for biosynthesis is given by the ratio of substrate oxidized exclusively for $\mathrm{NAD}(\mathrm{P}) \mathrm{H}$ production to the amount of substrate assimilated into cell carbon ( $a / b$ in Fig. I); for methylotrophs this may be estimated from the equations in Methods. When NAD(P)H is required for the initial hydroxylation, the ratio is always high for growth on methane (RMP, I. I3; SP, I.79), but otherwise the ratio is always low $(O \cdot 13)$ for bacteria using the ribulose monophosphate pathway. 
Table 2. The predicted effect of variations in $P / O$ ratios on cell yields during growth on methanol or methylamine

The $\mathrm{P} / \mathrm{O}$ ratios are the numbers of ATP molecules produced per atom of oxygen during oxidation of methanol or methylamine to formaldehyde $(\mathrm{X})$, formaldehyde to formate $(\mathrm{Y})$ and formate to $\mathrm{CO}_{2}(\mathrm{Z})$, this last step being catalysed by $\mathrm{NAD}^{+-}$-linked dehydrogenase. The predicted yield values are for methanol; they will also apply for growth on methylamine except that the $Y_{\mathrm{Sg}}$ values for methylamine will be $3 \%$ less than for methanol. The yields quoted are for bacteria in which only I mole of $\mathrm{NADH}$ is produced per mole of formaldehyde oxidized to $\mathrm{CO}_{2}$; when the yields are higher as a result of 2 moles of $\mathrm{NADH}$ being produced $\left(\mathrm{YH}_{2}=\mathrm{NADH}\right)$, the predicted yield is indicated by an asterisk $\left(^{*}\right), Y_{\mathrm{S}}, Y_{\mathrm{O}_{2}}$ and $Y_{\mathrm{CO}_{2}}$ are molar growth yields with respect to carbon substrate, oxygen and $\mathrm{CO}_{2} ; Y_{\mathrm{Sg}}$ is the yield (g dry weight bacteria) per g substrate. $\% \mathrm{CO}_{2}$ is the percentage of carbon substrate oxidized completely to $\mathrm{CO}_{2}\left(=100 Y_{\mathrm{s}} / Y_{\mathrm{CO}_{2}}\right)$.

\begin{tabular}{|c|c|c|c|c|c|c|c|c|c|c|c|c|}
\hline \multicolumn{3}{|c|}{$\mathrm{P} / \mathrm{O}$ ratio } & \multicolumn{5}{|c|}{ RMP-bacteria (FBP variant) } & \multicolumn{5}{|c|}{ SP-bacteria (icl+ variant) } \\
\hline $\mathrm{X}$ & $\mathrm{Y}$ & $\mathbf{Z}$ & $Y_{\mathrm{Sg}}$ & $Y_{\mathrm{s}}$ & $Y_{\mathrm{O}_{2}}$ & $Y_{\mathrm{CO}_{2}}$ & $\% \mathrm{CO}_{2}$ & $Y_{\mathrm{Sg}}$ & $Y_{\mathrm{s}}$ & $Y_{\mathrm{o}_{2}}$ & $Y_{\mathrm{CO}_{2}}$ & $\% \mathrm{CO}_{2}$ \\
\hline 2 & $3^{*}$ & 3 & & & & & & $0.64^{*}$ & $20 \cdot 4$ & $30 \cdot 6$ & I I I & 18 \\
\hline 2 & 3 & 3 & $0 \cdot 7 \mathrm{I}$ & $22 \cdot 7$ & $40 \cdot 8$ & $20 \cdot 4$ & II & 0.45 & $14 \cdot 2$ & $15 \cdot 7$ & $32 \cdot 3$ & 44 \\
\hline 2 & $2^{*}$ & 2 & & & & & & $0.60^{*}$ & $19 \cdot 1$ & $27 \cdot 8$ & $76 \cdot 5$ & 25 \\
\hline 2 & 2 & $\begin{array}{c}\mathrm{O}, \mathrm{I}, 2 \\
\text { or } 3\end{array}$ & $0.7 \mathrm{I}$ & $22 \cdot 7$ & $40 \cdot 8$ & $20 \cdot 4$ & I I & 0.45 & $14 \cdot 2$ & $15 \cdot 7$ & $32 \cdot 3$ & 44 \\
\hline 2 & $I^{*}$ & I & 0.71 & $22 \cdot 7$ & $40 \cdot 8$ & $20 \cdot 4$ & II & $0.55^{*}$ & $17 \cdot 5$ & $2 \mathrm{I} \cdot 8$ & $58 \cdot 3$ & 30 \\
\hline 2 & I & $\begin{array}{c}0,1,2 \\
\text { or } 3\end{array}$ & 0.67 & $2 \mathrm{I} \cdot 6$ & 36 & I 38 & 16 & 0.45 & $14 \cdot 2$ & I $5 \cdot 7$ & $32 \cdot 2$ & 44 \\
\hline I & $3^{*}$ & 3 & & & & & & $0.55^{*}$ & $17 \cdot 5$ & $22 \cdot 7$ & $6 \mathrm{I} \cdot 2$ & 29 \\
\hline I & 3 & 3 & 0.64 & 20.4 & $30 \cdot 6$ & 102 & 20 & 0.45 & $14 \cdot 2$ & $15 \cdot 7$ & $32 \cdot 2$ & 44 \\
\hline I & 2 & 3 & 0.62 & $19 \cdot 7$ & $29 \cdot 0$ & $87 \cdot 4$ & 22 & 0.45 & $14 \cdot 2$ & $15 \cdot 7$ & $32 \cdot 2$ & 44 \\
\hline I & $2^{*}$ & 2 & & & & & & $0.50^{*}$ & I $6 \cdot I$ & I9. I & $43 \cdot 7$ & 37 \\
\hline I & 2 & 2 & 0.60 & I9. I & $26 \cdot 6$ & $76 \cdot 5$ & 25 & 0.45 & $14 \cdot 2$ & $15 \cdot 7$ & $32 \cdot 2$ & 44 \\
\hline I & 2 & 0 & 0.56 & $17 \cdot 5$ & $22 \cdot 7$ & $55 \cdot 6$ & 29 & 0.45 & $14 \cdot 2$ & I 5.7 & $32 \cdot 2$ & 44 \\
\hline I & I & 3 & 0.58 & I 8.6 & $25 \cdot 5$ & 68.8 & 27 & 0.45 & $14 \cdot 2$ & I 5.7 & $32 \cdot 2$ & 44 \\
\hline I & I & 2 & 0.56 & I $8 \cdot 0$ & $22 \cdot 7$ & $6 I \cdot 0$ & 29 & 0.43 & 13.9 & 14.9 & $30 \cdot 6$ & 45 \\
\hline I & I & I & 0.52 & $16 \cdot 5$ & $20 \cdot 4$ & $47^{\circ} \mathrm{I}$ & 35 & $0.4 I$ & 13.0 & 13.6 & $26 \cdot 6$ & 49 \\
\hline I & I & 0 & 0.46 & 14.9 & $17 \cdot 0$ & $36 \cdot 0$ & 43 & 0.39 & I 2.5 & I 2.8 & $24 \cdot 5$ & $5 \mathrm{I}$ \\
\hline I & 0 & 3 & 0.55 & 17.5 & $22 \cdot 7$ & 55.6 & $3 I$ & 0.39 & 12.5 & I $2 \cdot 8$ & $24 \cdot 5$ & $5 \mathrm{I}$ \\
\hline I & 0 & 2 & 0.52 & 16.5 & 19.7 & $47 \cdot I$ & 35 & 0.38 & 12.0 & 12.0 & $22 \cdot 7$ & 53 \\
\hline I & 0 & I & 0.43 & I $4 \cdot 2$ & $15 \cdot 7$ & $32 \cdot 2$ & 44 & 0.31 & $9 \cdot 7$ & $8 \cdot 9$ & 15.7 & 62 \\
\hline I & 0 & 0 & 0.33 & $10 \cdot 6$ & $9 \cdot 9$ & 18.0 & 49 & 0.23 & $7 \cdot 4$ & $6 \cdot 3$ & 10.6 & $7 \mathrm{I}$ \\
\hline 0 & $3^{*}$ & 3 & & & & & & $0.48^{*}$ & I $5 \cdot 3$ & I 8.0 & $38 \cdot 3$ & 40 \\
\hline 0 & 3 & 3 & 0.55 & 17.5 & $22 \cdot 7$ & 55.6 & 35 & 0.44 & 14.2 & 15.7 & $32 \cdot 2$ & 44 \\
\hline 0 & 2 & 3 & 0.52 & I $6 \cdot 5$ & $19 \cdot 7$ & $47 \cdot \mathrm{I}$ & 35 & 0.43 & 13.6 & I $4 \cdot 6$ & $29 \cdot I$ & 47 \\
\hline 0 & 2 & 2 & 0.48 & 15.7 & 18.6 & $40 \cdot 8$ & 40 & 0.40 & I 2.8 & $13 \cdot 3$ & 25.5 & 50 \\
\hline 0 & 2 & I & 0.43 & 13.6 & $\mathrm{I} 4 \cdot 2$ & $29 \cdot I$ & 47 & 0.36 & I I 6 & I I $\cdot 3$ & $2 I \cdot I$ & 55 \\
\hline 0 & 2 & 0 & 0.36 & II 6 & I I $\cdot I$ & $2 I \cdot I$ & 55 & 0.34 & $10 \cdot 7$ & 10.2 & I 8.6 & $5^{8}$ \\
\hline 0 & I & 3 & 0.47 & 14.9 & 17.0 & 36.0 & 42 & 0.36 & I I I 6 & I I 3 & $2 I \cdot I$ & 55 \\
\hline 0 & I & 2 & 0.43 & 13.6 & 14.6 & $29 \cdot I$ & 47 & 0.34 & 10.9 & $10 \cdot 4$ & I9. I & 57 \\
\hline 0 & I & I & 0.35 & I I I I & 10.7 & 19.7 & 56 & 0.26 & 8.6 & $7 \cdot 6$ & 13.0 & 66 \\
\hline 0 & I & 0 & 0.23 & 7.5 & $6 \cdot 3$ & 10.6 & $7 \mathrm{I}$ & 0.19 & $6 \cdot 3$ & 5.0 & 8.3 & 76 \\
\hline 0 & 0 & 3 & 0.41 & 13.0 & I 3.6 & $26 \cdot 6$ & 49 & 0.28 & $9 \cdot 4$ & 8.5 & 14.9 & 66 \\
\hline 0 & 0 & 2 & 0.33 & 10.9 & 10.6 & I9. I & 59 & 0.22 & $7 \cdot 7$ & $6 \cdot 5$ & 10.9 & 71 \\
\hline 0 & 0 & I & 0.23 & $7 \cdot 2$ & 6.0 & $10 \cdot 0$ & 72 & 0.15 & 49 & $3 \cdot 8$ & $6 \cdot I$ & $8 I$ \\
\hline
\end{tabular}

The ratio for bacteria using the serine pathway or the ribulose bisphosphate pathway depends on the yield of $\mathrm{NAD}(\mathrm{P}) \mathrm{H}$ produced during oxidation of formaldehyde to $\mathrm{CO}_{2}$. When this yield is 2 , the ratio is fairly low (RBP, O.I3; SP, O.I9) but when the yield is only I then the ratio is high (RBP, I.I3; SP, 0.79). Ratios are always high on formate (RMP, $\mathrm{I} \cdot \mathrm{I} 3$; SP, I.79) and in $90 \%$ of methylotrophs for growth on dimethylamine and trimethylamine $(0.63$ to 4.38$)$. In contrast with these usually high values for methylotrophs, the ratios 
Table 3. The predicted effect of variations in the $P / O$ ratios on cell yields of

bacteria growing on methanol by way of the ribulose bisphosphate pathway

The $\mathrm{P} / \mathrm{O}$ ratios are the numbers of ATP molecules produced per atom of oxygen used during oxidation of methanol to formaldehyde $(\mathrm{X})$, formaldehyde to formate $(\mathrm{Y})$ and formate to $\mathrm{CO}_{2}(\mathrm{Z})$, this last step being catalysed to $\mathrm{NAD}^{+}$-linked dehydrogenase. $Y_{\mathrm{S}}, Y_{\mathrm{O}_{2}}$ and $Y_{\mathrm{CO}_{2}}$ are molar growth yields with respect to carbon substrate, oxygen and $\mathrm{CO}_{2} ; Y_{\mathrm{Sg}}$ is the yield (g dry weight bacteria) per $\mathrm{g}$ substrate. $\% \mathrm{CO}_{2}$ is the percentage of carbon substrate oxidized completely to $\mathrm{CO}_{2}$ $\left(=100 Y_{\mathrm{S}} / Y_{\mathrm{CO}_{2}}\right)$.

I mole of $N A D(P) H$ produced per

mole of $\mathrm{HCHO}$ oxidized to $\mathrm{CO}_{2}$

$\mathrm{P} / \mathrm{O}$ ratio

$\begin{array}{ccccccc}\mathrm{X}+\mathrm{Y} & \mathrm{Z} & Y_{\mathrm{Sg}} & Y_{\mathrm{S}} & Y_{\mathrm{O}_{2}} & Y_{\mathrm{CO}_{2}} & \% \mathrm{CO}_{2} \\ 3-5 & 0-3 & 0.38 & \mathrm{I} 2.0 & \mathrm{I} 2.0 & 22.7 & 53 \\ 2 & 3 & 0.35 & \mathrm{II} \cdot \mathrm{I} & 10.7 & 19.7 & 56 \\ 2 & 2 & 0.34 & \mathrm{I} 0.9 & 10.5 & 19.1 & 57 \\ 2 & 0 & 0.3 \mathrm{I} & \mathrm{I} 0.0 & 9.3 & 16.5 & 6 \mathrm{I} \\ \mathrm{I} & 3 & 0.28 & 8.9 & 7.9 & 13.6 & 66 \\ \mathrm{I} & 2 & 0.26 & 8.2 & 7.0 & 12.0 & 68 \\ \mathrm{I} & 1 & 0.22 & 7.0 & 5.8 & 9.7 & 72 \\ \mathrm{I} & 0 & 0.16 & 5.0 & 3.9 & 6.3 & 79 \\ 0 & 3 & 0.2 \mathrm{I} & 6.7 & 5.5 & 9.1 & 74 \\ 0 & 2 & 0.17 & 5.5 & 4.3 & 7.0 & 79 \\ 0 & \mathrm{I} & 0.11 & 3.5 & 2.6 & 4.1 & 85\end{array}$

2 moles of $N A D(P) H$ produced per mole of $\mathrm{HCHO}$ oxidized to $\mathrm{CO}_{2}$

$\mathrm{P} / \mathrm{O}$ ratio

\begin{tabular}{cccrrrc}
$\mathrm{X}$ & $\mathrm{Y}+\mathrm{Z}$ & $Y_{\mathrm{sg}}$ & \multicolumn{1}{c}{$Y_{\mathrm{S}}$} & \multicolumn{1}{c}{$Y_{\mathrm{O}_{2}}$} & $Y_{\mathrm{CO}_{2}}$ & $\% \mathrm{CO}_{2}$ \\
2 & 6 & 0.55 & 17.5 & 23.5 & 55.6 & 33 \\
2 & 4 & 0.49 & 15.7 & 20.4 & 40.8 & 39 \\
$\mathrm{I}$ & 6 & 0.47 & 14.9 & $\mathrm{I} 7.5$ & 36.0 & $4 \mathrm{I}$ \\
2 & 2 & 0.43 & 13.9 & 15.7 & 30.6 & 45 \\
$\mathrm{I}$ & 4 & 0.42 & 13.3 & 14.6 & 27.8 & 48 \\
0 & 6 & $0.4 \mathrm{I}$ & 13.0 & 13.9 & 19.7 & 66 \\
0 & 4 & 0.33 & 10.7 & 10.6 & 18.6 & 58 \\
$\mathrm{I}$ & 2 & 0.33 & 10.4 & 10.0 & 17.5 & 59 \\
2 & 0 & 0.31 & 10.0 & 9.4 & 16.5 & $6 \mathrm{I}$ \\
0 & 2 & 0.22 & 7.0 & 5.8 & 9.6 & 73 \\
$\mathrm{I}$ & 0 & 0.16 & 5.0 & 3.9 & 6.3 & 79
\end{tabular}

Table 4. The predicted effect of variations in $P / O$ ratios on cell yields during growth on formaldehyde or formate

The $\mathrm{P} / \mathrm{O}$ ratios are the numbers of ATP molecules produced per atom of oxygen used during oxidation of formaldehyde to formate $(\mathrm{Y})$ and formate to $\mathrm{CO}_{2}(\mathrm{Z})$, this last step being catalysed by $\mathrm{NAD}^{+}$-linked dehydrogenase. The yields quoted are for bacteria in which only I mole of NADH is produced per mole of formaldehyde oxidized to $\mathrm{CO}_{2}$; when the yields are higher as a result of 2 moles of $\mathrm{NAD}(\mathrm{P}) \mathrm{H}$ being produced $\left(\mathrm{YH}_{2}=\mathrm{NADH}\right)$, the predicted yield is indicated by an asterisk $\left(^{*}\right) . Y_{\mathrm{s}}, Y_{\mathrm{O}_{2}}$ and $Y_{\mathrm{CO}_{2}}$ are molar growth yields with respect to carbon substrate, oxygen and $\mathrm{CO}_{2} ; Y_{\mathrm{Sg}}$ is the yield (g dry weight bacteria) per g substrate. $\% \mathrm{CO}_{2}$ is the percentage of carbon substrate oxidized completely to $\mathrm{CO}_{2}\left(=100 Y_{\mathrm{S}} / Y_{\mathrm{CO}_{2}}\right)$. During growth on formate the only source of ATP is from phosphorylation coupled to oxidation of NADH.

\begin{tabular}{|c|c|c|c|c|c|c|c|c|c|c|c|}
\hline \multicolumn{2}{|c|}{$\mathrm{P} / \mathrm{O}$ ratio } & \multicolumn{5}{|c|}{ RMP-bacteria (FBP variant) } & \multicolumn{5}{|c|}{ SP-bacteria (icl ${ }^{+}$variant) } \\
\hline $\mathrm{Y}$ & $\mathbf{Z}$ & $Y_{\mathrm{Sg}}$ & $Y_{\mathrm{s}}$ & $Y_{\mathrm{O}_{2}}$ & $Y_{\mathrm{CO}_{2}}$ & $\% \mathrm{CO}_{2}$ & $Y_{\mathrm{sg}}$ & $Y_{\mathrm{s}}$ & $Y_{\mathrm{O}_{2}}$ & $Y_{\mathrm{CO}_{2}}$ & $\% \mathrm{CO}_{2}$ \\
\hline \multicolumn{12}{|c|}{ Bacteria growing on formaldehyde } \\
\hline $3^{*}$ & 3 & & & & & & $0.52^{*}$ & $15 \cdot 5$ & $40 \cdot 8$ & $39 \cdot 5$ & 39 \\
\hline 3 & 3 & 0.57 & 17.0 & $58 \cdot 3$ & $5 \mathrm{I} \cdot 0$ & $3 I$ & 0.47 & 14.2 & $35 \cdot 0$ & $32 \cdot 3$ & 44 \\
\hline 2 & 3 & 0.55 & $16 \cdot 5$ & $53 \cdot 2$ & $47 \cdot I$ & 35 & 0.45 & I 3.6 & $3 I \cdot 4$ & $29 \cdot I$ & 47 \\
\hline 2 & 2 & $0.5 \mathrm{I}$ & $15 \cdot 3$ & $42 \cdot 2$ & $38 \cdot 3$ & 40 & 0.43 & I $2 \cdot 8$ & $27 \cdot 2$ & 25.5 & 50 \\
\hline 2 & I & 0.45 & 13.6 & $31 \cdot 4$ & $29 \cdot I$ & 47 & 0.39 & $11 \cdot 6$ & $2 I \cdot 9$ & $2 I \cdot I$ & 55 \\
\hline 2 & $\circ$ & 0.38 & II 5 & $22 \cdot 3$ & $2 I \cdot I$ & 57 & 0.36 & $10 \cdot 7$ & $19 \cdot 4$ & I $8 \cdot 6$ & 58 \\
\hline $\mathbf{I}$ & 3 & 0.50 & 14.9 & $38 \cdot 3$ & 36 & $4 \mathrm{I}$ & 0.39 & $11 \cdot 6$ & $2 I \cdot 9$ & $2 I \cdot I$ & 55 \\
\hline I & 2 & 0.45 & 13.6 & $3 I \cdot 4$ & $29 \cdot I$ & 47 & 0.31 & $9 \cdot 2$ & 14.9 & 14.4 & 64 \\
\hline$I$ & I & 0.37 & II $\cdot I$ & 20.4 & 19.7 & 56 & 0.29 & $8 \cdot 6$ & 13.3 & 13.0 & 66 \\
\hline I & o & 0.25 & $7 \cdot 5$ & $10 \cdot 8$ & 10.6 & 72 & $0.2 \mathrm{I}$ & $6 \cdot 2$ & $8 \cdot 4$ & $8 \cdot 3$ & 75 \\
\hline 0 & 3 & 0.43 & $13 \cdot 0$ & $27 \cdot 8$ & $26 \cdot 6$ & 49 & 0.31 & 9.4 & $15 \cdot 3$ & 14.9 & 63 \\
\hline 0 & 2 & 0.36 & 10.9 & $20 \cdot I$ & $19^{\circ} \mathrm{I}$ & 57 & 0.26 & $7 \cdot 7$ & II $\cdot I$ & 10.9 & $7 I$ \\
\hline 0 & I & 0.24 & $7 \cdot 2$ & $10 \cdot 3$ & $10 \cdot 0$ & 72 & 0.16 & 4.9 & $6 \cdot 2$ & $6 \cdot I$ & 80 \\
\hline \multicolumn{12}{|c|}{ Bacteria growing on formate } \\
\hline & 3 & 0.17 & $7 \cdot 8$ & $43 \cdot 7$ & II $\cdot I$ & 70 & 0.15 & $7 \cdot 0$ & $34 \cdot 0$ & $9 \cdot 7$ & 72 \\
\hline & 2 & 0.15 & $6 \cdot 7$ & 29.9 & $9 \cdot 0$ & 74 & 0.13 & 59 & $23 \cdot I$ & $7 \cdot 7$ & 77 \\
\hline & I & 0.10 & $4 \cdot 6$ & 14.0 & $5 \cdot 6$ & 82 & 0.09 & $3 \cdot 9$ & I I 6 & $4 \cdot 6$ & 85 \\
\hline
\end{tabular}


for most typical heterotrophic growth substrates are zero or less than $0 \cdot 08$; the only exceptions among common growth substrates are pyruvate (0.35), glycollate, glyoxylate and glycine (all $\mathrm{I} \cdot 05)$ and oxalate $(2 \cdot 92)$.

In most methylotrophs a second condition for $\mathrm{NAD}(\mathrm{P}) \mathrm{H}$ limitation applies and this may result in such an extensive $\mathrm{NAD}(\mathrm{P}) \mathrm{H}$ limitation that the ATP supply becomes relatively unimportant in determining growth yields. This second condition is that oxidation of growth substrate to supply carbon precursors and $\mathrm{NAD}(\mathrm{P}) \mathrm{H}$ for biosynthesis should also produce further additional reducing equivalents [other than $\mathrm{NAD}(\mathrm{P}) \mathrm{H}$, whose oxidation by molecular oxygen may also be coupled to ATP generation (summarized in Fig. 1). This ATP is not expressed in terms of extra substrate molecules in the equation for assimilation of the substrate because these molecules are already included as the source of NAD $(P) H$ which is essential to give cell material of the appropriate level of reduction. If the ATP yield from oxidation of these reducing equivalents [other than $\mathrm{NAD}(\mathrm{P}) \mathrm{H}$ ] is sufficient for growth then the growth yield will be exclusively NAD(P)H-limited (rather than ATPlimited) and the direct relationships between $\mathrm{P} / \mathrm{O}$ ratio, $Y_{0_{2}}, Y_{\mathrm{S}}$ and $Y_{\mathrm{ATP}}$ values will not apply. Should further ATP be required then the $\mathrm{P} / \mathrm{O}$ ratio will determine how much more substrate must be oxidized to provide this. If this further ATP requirement is relatively small then the value of the $\mathrm{P} / \mathrm{O}$ ratio will have little effect on the growth yield and the bacteria will still be predominantly $\mathrm{NAD}(\mathrm{P}) \mathrm{H}$-limited. If the ATP requirement for assimilation is very high then the supply of ATP, and hence the $\mathrm{P} / \mathrm{O}$ ratio, will be relatively more important in determining growth yields. The enzymic basis for this unusual situation leading to the second condition for $\mathrm{NAD}(\mathrm{P}) \mathrm{H}$ limitation in methylotrophs is that the final oxidation step, catalysed by formate dehydrogenase, is often the only source of $\mathrm{NAD}(\mathrm{P}) \mathrm{H}$, and the dehydrogenases for methanol and for methylamine do not give rise to NAD(P)H. In typical heterotrophs, by contrast, the only alternative source of reducing power is usually reduced flavoprotein and the amount of this is small compared with the amount of NAD(P)H produced during oxidation of most substrates.

\section{The influence of $N A D(P) H$ supply on predicted cell yields}

The only methylotrophs in which neither of the conditions for NAD(P)H limitation occur are RMP-bacteria growing on formaldehyde (Table 4) or on methane (M hydroxylation system) (Table I). If the oxygen used in the initial hydroxylation of methane is omitted from the equations for calculation of $Y_{\mathrm{O}_{2}}$ values, then these bacteria are similar to typical heterotrophs in that the $Y_{\mathrm{O}_{2}}$ value varies directly with the $\mathrm{P} / \mathrm{O}$ ratio. As can be seen from the predictions in Table 4 this relationship is also true for bacteria growing on formate. These bacteria have a high requirement for $\mathrm{NAD}(\mathrm{P}) \mathrm{H}$ and in one sense the supply of $\mathrm{NAD}(\mathrm{P}) \mathrm{H}$ will limit growth; however, as mentioned above, this limitation can be expressed as an ATP limitation because oxidation of formate yields only NADH and this may be used either for biosynthesis or for ATP generation.

In all other methylotrophs, both conditions for $\mathrm{NAD}(\mathrm{P}) \mathrm{H}$ limitation of growth yields are satisfied and the predictions in Tables $\mathrm{I}$ to 4 confirm this. At lower $\mathrm{P} / \mathrm{O}$ ratios the growth yields ( $Y_{\mathrm{S}}$ and $Y_{\mathrm{O}_{2}}$ values) are related to some extent to the $\mathrm{P} / \mathrm{O}$ ratios but at higher $\mathrm{P} / \mathrm{O}$ ratios growth is sometimes exclusively $\mathrm{NAD}(\mathrm{P}) \mathrm{H}$-limited, and very small (or zero) increases in yield are predicted for large increases in $\mathrm{P} / \mathrm{O}$ ratios. The most marked limitation by $\mathrm{NAD}(\mathrm{P}) \mathrm{H}$ supply is predicted in serine pathway bacteria such as Pseudomonas AMI in which neither methanol, methylamine nor formaldehyde oxidation is coupled to generation of $\mathrm{NADH}$. In these bacteria, measured $Y_{\mathrm{mg}}$ values of more than about $0.4 \mathrm{~g}$ per $\mathrm{g}$ methanol or methylamine clearly cannot be used for prediction of $\mathrm{P} / \mathrm{O}$ ratios, or vice versa; even with lower growth yields than this the prediction of $\mathrm{P} / \mathrm{O}$ ratios from measured growth yields cannot be accurate. For example, in a recent valuable investigation, Goldberg et al. (1976) showed that yield values $\left(Y_{\mathrm{sg}}\right)$ for growth of serine pathway bacteria on methanol, methylamine and formaldehyde were in the range where $\mathrm{NAD}(\mathrm{P}) \mathrm{H}$ limitation is considerable 
(e.g. 0.3 to $0.4 \mathrm{I}$ ) and hence their estimates of $\mathrm{P} / \mathrm{O}$ ratios based on these yield values require confirmation by alternative methods.

The pronounced $\mathrm{NAD}(\mathrm{P}) \mathrm{H}$ limitation of growth yield in methylotrophs as discussed here was not so apparent in the predictions of van Dijken \& Harder (1975) because, in their formulations for growth on methanol by the serine pathway, they 'equated' reduced flavoprotein $\left(\mathrm{FPH}_{2}\right)$ with NADH by increasing the ATP requirement for assimilation of methanol into phosphoglycerate, thus in effect assuming reversed electron transport to achieve production of $\mathrm{NAD}(\mathrm{P}) \mathrm{H}$. Reversed electron transport has not been demonstrated in methylotrophs but if it does occur then a potential high ATP yield could be 'converted' to $\mathrm{NAD}(\mathrm{P}) \mathrm{H}$ and hence to higher cell yields than those predicted here for $\mathrm{NAD}(\mathrm{P}) \mathrm{H}$-limited bacteria.

This effect of reversed electron transport on yields of methane-utilizing bacteria has been calculated by van Dijken \& Harder (1975) and they have pointed out that if methane is oxidized by an NAD(P)H-dependent hydroxylase then high growth yields of RMP-bacteria $\left(Y_{s}>12 ; Y_{\mathrm{sg}}>0.75\right)$ can only occur if reversed electron transport operates. This view is supported by the predictions in the present paper (Table I). The high yields that have been reported for RMP-bacteria growing on methane $\left(Y_{\mathrm{sg}}>0.75\right)$ could arise because reversed electron transport is operating or because such bacteria (giving high yields) have the cytochrome $c / \mathrm{MDH}$-linked hydroxylase system (M system). It is worth noting that in these bacteria molar growth yields on methane should be similar in value to those on methanol (Tables $\mathrm{I}$ and 2) for a given $\mathrm{P} / \mathrm{O}$ ratio. High molar growth yields, which are similar on methane or methanol, have been quoted as circumstantial evidence for an alternative mechanism for methane oxidation which involves free radicals (Hutchinson, Whittenbury \& Dalton, 1976). This mechanism does not require (nor produce) reducing equivalents during oxidation of methane to methanol and hence reversed electron transport will not be necessary and molar growth yields ( $Y_{\mathrm{s}}$ and $Y_{\mathrm{CO}_{2}}$ but not $Y_{\mathrm{O}_{2}}$ ) will be identical to the values predicted for growth on methanol (Table 2 ).

\section{The influence of assimilation pathways on predicted cell yields}

As predicted by van Dijken \& Harder (I975), for a given P/O ratio lower growth yields are predicted for SP-bacteria than for RMP-bacteria; the relative yields depend on the growth substrate under consideration (methane, I5 to $20 \%$ lower; methanol and methylamine, 6 to $40 \%$, usually about $30 \%$; formaldehyde, 7 to $30 \%$; formate, 6 to $13 \%$ ). When the Entner-Doudoroff variant operates in RMP-bacteria, yields will be 6 to $15 \%$ lower than in bacteria with the FBP variant of this pathway (the greater percentage difference occurs at higher $\mathrm{P} / \mathrm{O}$ ratios).

Operation of the ribulose bisphosphate pathway during growth on methanol gives about half the cell yield compared with that predicted for RMP-bacteria, this difference usually being less if the oxidation of formaldehyde to $\mathrm{CO}_{2}$ yields 2 molecules of $\mathrm{NAD}(\mathrm{P}) \mathrm{H}$. In SP-bacteria, predicted yields will be up to $10 \%$ lower if succinate dehydrogenase is not coupled to ATP synthesis. Furthermore, if oxidation of acetate to glyoxylate yields no reducing equivalents then predicted yields will be 7 to $20 \%$ less than for bacteria with the icl variant of the serine pathway.

The influence on predicted cell yields of the nature of the pathways for oxidation of methane, methanol, methylamine, formaldehyde and NADH

By reference to the Tables it is possible to predict the effect of various $\mathrm{P} / \mathrm{O}$ ratios on cell yields. In addition, it can be seen that the nature of the various oxidation pathways may also have a further separate influence.

A major influence on cell yields during growth on methane, methanol or methylamine is the nature of the system for oxidation of formaldehyde; this is because although $\mathrm{NAD}(\mathrm{P}) \mathrm{H}$ is often essential for reduction of formaldehyde to phosphoglycerate and for 
methane hydroxylation, NADH is never produced in the initial oxidation of growth substrate to formaldehyde. In the absence of reversed electron transport systems, bacteria that require $\mathrm{NAD}(\mathrm{P}) \mathrm{H}$ for methane hydroxylation must be able to obtain 2 molecules of $\mathrm{NAD}(\mathrm{P}) \mathrm{H}$ per molecule of formaldehyde oxidized to $\mathrm{CO}_{2}$. For these bacteria growth yields are up to $30 \%$ lower for a given $\mathrm{P} / \mathrm{O}$ ratio than for bacteria with the alternative system (M system) for methane hydroxylation.

The nature of the formaldehyde-oxidizing system also influences yields of bacteria growing on methanol by way of the ribulose bisphosphate pathway or the serine pathway, higher yields being predicted if 2 molecules of $\mathrm{NAD}(\mathrm{P}) \mathrm{H}$ are produced per molecule of formaldehyde oxidized to $\mathrm{CO}_{2}$; this effect is only predicted at higher $\mathrm{P} / \mathrm{O}$ ratios where the $\mathrm{NAD}(\mathrm{P}) \mathrm{H}$ limitation has a greater effect on yield. The nature of the system for oxidation of formaldehyde has very little effect on the yield of RMP-bacteria during growth on methanol, methylamine, formaldehyde or formate.

It can be seen from the Tables that although ATP generation coupled to the oxidation of methanol to formaldehyde may often be the main source of ATP (as in bacteria growing on methane using the NADH-requiring methane hydroxylation system) it is rarely absolutely essential for growth. Similarly, coupling of ATP generation to NADH oxidation is only absolutely essential for growth on formate. In many situations, if ATP is produced during oxidation of either methanol or NADH then coupling of both these oxidation systems to ATP formation often leads to relatively minor increases in cell yields.

\section{Predicted growth yields on dimethylamine and trimethylamine}

If the oxidation of dimethylamine and trimethylamine to methylamine is by way of dehydrogenase-catalysed reactions then predicted yields are essentially the same as for methylamine and methanol; $Y_{\mathrm{O}_{2}}$ and $Y_{\mathrm{CO}_{2}}$ values will be identical whereas $Y_{\mathrm{S}}$ values will be doubled for dimethylamine, and trebled for trimethylamine.

If oxidation (to methylamine) of dimethylamine and trimethylamine is catalysed by $\mathrm{NAD}(\mathrm{P}) \mathrm{H}$-requiring mono-oxygenases then the NAD(P)H supply is often growth-limiting. Once again the yield of NAD(P)H from formaldehyde oxidation is an important consideration. If this yield is 2 molecules then the growth yields are determined to some extent by the $\mathrm{P} / \mathrm{O}$ ratios for oxidation of methylamine to formaldehyde and for $\mathrm{NADH}$ oxidation. However if oxidation of formaldehyde to formate only provides I molecule of NADH, then ATP supply has little effect on cell yields.

For growth of RMP-bacteria on dimethylamine, if the total yield of ATP from oxidation of methylamine to formate is only 2 then the maximum cell yield is obtained $\left(Y_{\mathrm{s}}, 22 \cdot 7\right)$, and higher $\mathrm{P} / \mathrm{O}$ ratios, or coupling of $\mathrm{NADH}$ oxidation to generation of $\mathrm{ATP}$, will not increase this yield. This is also true for growth on dimethylamine by the serine pathway and for growth on trimethylamine (involving either pathway), but with the further remarkable prediction that provided I molecule of ATP is produced in the oxidation of formaldehyde to formate then coupling of oxidation of NADH or methylamine to ATP generation will not increase cell yields. The maximum $Y_{\mathrm{s}}$ values achieved will be $22 \cdot 7$ for growth involving the ribulose monophosphate pathway and $14 \cdot 2$ for growth by the serine pathway.

\section{The concept of $Y_{\mathrm{ATP}}$ value in methylotrophs}

The concept of $Y_{\mathrm{ATP}}$ (yield of cell material per mole of ATP available for biosynthesis) clearly assumes that cell yields are directly related to ATP yields from substrate oxidation (this may be expressed as $Y_{\mathrm{O}}=Y_{\mathrm{ATP}} \times \mathrm{P} / \mathrm{O}$ ratio) and this assumption has been the basis for prediction of cell yields of methylotrophs. However the concept of $Y_{\mathrm{ATP}}$ loses its meaning for those methylotrophs where both conditions for $\mathrm{NAD}(\mathrm{P}) \mathrm{H}$ limitation operate, and for these bacteria estimates of $Y_{\text {ATP }}$ from measurements of growth yields and $\mathrm{P} / \mathrm{O}$ ratios will not be valid. (In the present paper the use of $Y_{\mathrm{ATP}}$ values, measured in other bacteria, for estimating the ATP requirement for biosynthesis from PGA is acceptable because it 
assumes only that the efficiency of utilization of PGA for biosynthesis is the same in methylotrophs as in typical heterotrophs.)

Harder \& van Dijken (1976) have recently modified their earlier method of predicting yields of methylotrophs growing on methane by estimating the ATP requirement for biosynthesis from calculated $Y_{\text {ATP }}$ values. They estimated a theoretical $Y_{\operatorname{maxATP}}$ for methane and then calculated a $Y_{\text {ATP }}$ value from this for a given growth rate $(\mu)$, maintenance energy $\left(\mathrm{m}_{\mathrm{e}}\right)$ and coupling constant $(k)$ using the formula:

$$
\frac{\mathrm{I}}{Y_{\mathrm{ATP}}}=\frac{\mathrm{m}_{\mathrm{e}}}{\mu}+\frac{\mathrm{I}}{k \cdot Y_{\operatorname{maxATP}}} .
$$

The coupling constant $(k)$ was the observed $Y_{\text {ATP }}$ value for glucose corrected for maintenance, divided by the $Y_{\operatorname{maxATP}}$ calculated for the assimilation of glucose and is an indication of 'energy lost due to a certain amount of uncoupling of energy generation and growth' (Harder \& van Dijken, 1976). However, the use of this coupling constant, relating to glucose assimilation in typical ATP-limited heterotrophic bacteria will not be suitable for use in $\mathrm{NAD}(\mathrm{P}) \mathrm{H}$-limited methylotrophs where uncoupling of energy (ATP) generation from growth may be extensive. Thus although this formula may be useful for predicting cell yields in typical heterotrophs and in some methylotrophs it is clear that it should be used with care for relating maintenance energies, coupling constants and $Y_{\mathrm{ATP}}$ values in those methylotrophs that are partly, or completely, NAD(P)H-limited.

I should like to think the Science Research Council for support of work that stimulated the production of this paper, and David O'Keeffe for useful discussions during its preparation.

\section{REFERENCES}

ALEem, M. I. H. (1977). Coupling of energy with electron transfer reactions in chemolithotrophic bacteria. Symposia of the Society for General Microbiology 27, 35I-382.

ANTHONY, C. (1975a). The biochemistry of methylotrophic micro-organisms. Science Progress (Oxford) 62, 167-206.

Anthony, C. $(1975 b)$. The microbial metabolism of $\mathrm{C}_{1}$ compounds: the cytochromes of Pseudomonas AMI. Biochemical Journal 146, 289-298.

Anthony, C. \& O'KeEFFe, D. T. (1977). Proton translocation in a mutant of Pseudomonas AMI lacking cytochrome $c$. Proceedings of the Society for General Microbiology 4, 68.

ANTHONY, C. \& ZATMAN, L. J. (1967). The microbial oxidation of methanol. The prosthetic group of the alcohol dehydrogenase of Pseudomonas sp. M27; a new oxidoreductase prosthetic group. Biochemical Journal 104, 960-969.

Barnes, L. J., Drozd, J. W., Harrison, D. E. F. \& HAMER, G. (1976). Process considerations and techniques specific to protein production from natural gas. In Microbial Production and Utilization of Gases, pp. 30I-315. Edited by H. G. Schlegel, N. Pfennig and G. Gottschalk. Göttingen: E. Goltze Verlag.

Colby, J. \& Dalton, H. (1976). Some properties of a soluble methane mono-oxygenase from Methylococcus capsulatus strain Bath. Biochemical Journal 157, 495-497.

Colby, J. \& Zatman, L. J. (I975). Enzymological aspects of the pathways for trimethylamine oxidation and $C_{1}$ assimilation in obligate methylotrophs and restricted facultative methylotrophs. Biochemical Journal 148, 513-520.

Colby, J., Dalton, H. \& Whittenbury, R. (I975). An improved assay for bacterial methane monooxygenase: some properties of the enzyme from Methylomonas methanica. Biochemical Journal I5I, 459-462.

Colby, J., Stirling, D. I. \& Dalton, H. (1977). The soluble methane mono-oxygenase of Methylococcus capsulatus (Bath); its ability to oxygenate $n$-alkanes, $n$-alkenes, ethers, alicyclic, aromatic and heterocyclic compounds. Biochemical Journal I65, 395-402.

CoX, R. B. \& QUAYLE, J. R. (1975). The autotrophic growth of Micrococcus denitrificans on methanol. Biochemical Journal 150, 569-57I.

VAN DiJken, J. P. \& HARder, W. (1975). Growth yields of microorganisms on methanol and methane. A theoretical study. Biotechnology and Bioengineering 17, 15-30.

Farmer, I. S. \& Jones, C. W. (1976). The energetics of Escherichia coli during aerobic growth in continuous culture. European Journal of Biochemistry 67, I I 5-I 22.

Goldberg, I., Rock, J. S., Ben-Bassat, A. \& MATELES, R. I. (1976). Bacterial yields on methanol, methylamine, formaldehyde and formate. Biotechnology and Bioengineering 18, I657-1 668.

HARder, W. \& VAN DiJKen, J. P. (1976). Theoretical considerations on the relation between energy production and growth of methane-utilizing 
bacteria. In Microbial Production and Utilization of Gases, pp. 403-418. Edited by H. G. Schlegel, N. Pfennig and G. Gottschalk. Göttingen: E. Goltze Verlag.

harrison, D. E. F., Topimala, H. H. \& Hamer, G. (1972). Yield and productivity in single-cell protein production from methane and methanol. In Fermentation Technology Today, pp. 49I-495. Edited by G. Turui. Kyoto: Society of Fermentation Technology, Japan.

hutchinson, D. W., Whittenbury, R. \& Dalton, H. (1976). A possible role of free radicals in the oxidation of methane by Methylococcus capsulatus. Journal of Theoretical Biology $\mathbf{5 8}$, 325-335.

JONES, O. T. G. (I 977). Electron transport and ATP synthesis in the photosynthetic bacteria. Symposia of the Society for General Microbiology 27, 15II 84 .

LARGe, P. J. (1971). The oxidative cleavage of alkylnitrogen bonds in micro-organisms. Xenobiotica $\mathbf{r}$, $457-467$.

Maclennan, D. G., Ousby, J. C., Vasey, R. B. \& Cotton, N. T. (1971). The influence of dissolved oxygen on Pseudomonas Am grown on methanol in continuous culture. Journal of General Microbiology 69, 395-404.

Newaz, S. S. \& Hersh, L. B. (1975). Reduced nicotinamide adenine dinucleotide-activated phosphoenolpyruvate carboxylase in Pseudomonas ma: potential regulation between carbon assimilation and energy production. Journal of Bacteriology I24, $825-833$.
O'Kfeffe, D. T. \& Anthony, C. (1977). Proton translocation in the facultative methylotroph Pseudomonas Ami. Proceedings of the Society for General Microbiology 4, 67.

O'Keefe, D. T. \& AnThony, C. (1978). The microbial metabolism of $\mathrm{C}_{1}$ compounds. The stoicheiometry of respiration-driven proton translocation in Pseudomonas AMI and in a mutant lacking cytochrome c. Biochemical Journal (in the Press).

Stouthamer, A. H. (1977). Energetic aspects of the growth of micro-organisms. Symposia of the Society for General Microbiology 27, 285-315.

Strøm, T., Ferenci, T. \& Quayle, J. R. (1974). The carbon assimilation pathways of Methylococcus capsulatus, Pseudomonas methanica and Methylosinus trichosporium (ОВ3В) during growth on methane. Biochemical Journal 144, 465-476.

Tonge, G. M., Drozd, J. W. \& Higgins, I. J. (1977a). Energy coupling in Methylosinus trichosporium. Journal of General Microbiology 99, 229-232.

Tonge, G. M., Harrison, D. E. F. \& Higgins, I. J. $(1977 b)$. Purification and properties of the methane mono-oxygenase enzyme system from Methylosinus trichosporium, овzb. Biochemical Journal I6I, 333-344.

Whittenbury, R. \& Kelly, D. P. (1977). Autotrophy, a conceptual phoenix. Symposia of the Society for General Microbiology 27, 12 I-149.

Widdowson, D. \& ANTHONY, C. (1975). The microbial metabolism of $C_{1}$ compounds. The electron transport chain of Pseudomonas AMI. Biochemical Journal r52, 349-356. 